so difficult. Skinner's contribution, first acting in Cockcroft's absence and later as one of his able lieutenants, was a most important one. His particular personal creation was the General Physics Division which, organizationally, could have no logical justification but was a reflexion of his own wide interests and was extremely productive. Under his personal supervision came the synchrocyclotron, cloud chamber and nuclear emulsion work, synchrotrons, linear accelerators and electronics instrumentation, X-ray and neutron diffraction, isotope separation and mass spectrometry, and, later, extra-mural work on plasma physics. All this work prospered and, with the growth of Harwell, some found homes in new divisions.

Four years later, when chief physicist at Harwell, Skinner was appointed to succeed Sir James Chadwick at Liverpool. There he had further opportunity to exploit his talent for construction, because Chadwick, having created a flourishing school of nuclear physies around one of the first cyclotrons in Europe, had undertaken the construction of a new research laboratory centred on a 156-in. synchrocyclotron. This large project was in an early and critical stage, but was brought to a highly successful conclusion with the help of Chadwick's former colleagues and new men brought in by Skinner. Unlike Chadwick, Skinner was not primarily a nuclear physicist, and he appointed J. M. Cassels as professor of experimental physics. Liverpool became the home of a powerful school of high-energy physies, and the research work more than kept pace with the general growth in the universities. The small cyclotron, together with a Cockcroft-Walton generator, enabled the traditional nuclear physics school at Liverpool to grow in size and output to such good effect that one of Skinner's last acts was to undertake the installation of a tandem electrostatic generator for further expansion in this field. This machine is still being manufactured, and it is tragic that Skinner will not see it installed. A new and impressive building, the Chadwick Physics Laboratory, for teaching and research was completed recently under his guidance.

Skinner was active in the work of the European Organization for Nuclear Research (CERN) and was the senior British consultant in the $600-\mathrm{MeV}$. synchrocyclotron project. He was chairman of the CERN Panel of the Department of Scientific and Industrial Research, concerned with British participation in CERN'S work, and served on the Nuclear Physics Sub-Committee. He remained keenly interested in atomic energy, and was a consultant to the Atomic Energy Authority and a member of the Nimrod Project Committee. The National Institute for Research in Nuclear Science has good reason to be grateful for his advice and help on numerous occasions, and he was an active and provocative member of several committees of the Institute. He brought his laboratory into the national Liquid Hydrogen Bubble Chamber project sponsored by several British universities.

Herbert Skinner was devoted to physics and to physicists, and was generous with his time and energies. He hated red tape and sometimes alarmed administrators. Unconventional, persistent in argument and often disconcerting in management, he was also sincere, gentle and kind to an extent not always understood by his critics. $\mathrm{He}$ and his wife Erna were generous in hospitality, and their home was often crowded with guests. The affairs of physicists are duller without him.

T. G. Pickavance

\section{Prof. Marcel Schein}

$\mathrm{ON}_{\mathrm{N}}$ February 20, at the height of his sciontific career, Marcel Schein died in Chicago, Illinois. With him disappeared a most brilliant, able and imaginative scientist whose work is destined to leave an enduring mark in the physies of our century.

Marcel Schein was born in Tresten, Czechoslovakia, on June 9, 1902. After studying in Prague, Vienna, Würtzburg and Zurich, he received a doctorate in physies at the University of Zurich in 1927. His first academic appointment was that of assistant in physics in that University. Between 1929 and 1930 he spent a year in Chicago on a Rockefeller Fellow. ship. He then returned to Zurich as a docent, a position which he held until 1935, when he was appointed professor of physics at the University of Odessa. In 1938, Mareel Schein wont to settle permanently in the United States, at the invitation of Prof. A. H. Compton. He joined the University of Chicago where he remained until his death, holding various positions until, in 1946, he was appointed professor in the Department of Physics and in the Institute of Nuclear Studies. In 1927, while in Zurich, he married the former Hilde Schoenbeck, who was working as a Ph.D. candidate in the Physics Department. From this marriage he had a son, Edgar, who is now on the faculty of the School of Industrial Management at the Massachusetts Institute of Technology.

In the early years of his scientific career, Marcel Schein made some valuable contributions to the physics of X-rays. $\mathrm{He}$ is best known, however, for his work in cosmic rays, which he began after moving to Chicago in 1938. At that time it was known that the primary radiation consisted, at least to a large extent, of positively charged particles. The possibility that these particles might be protons had been suggested ; however, there was no direct experimental evidence to support this assumption. Indeed, the prevailing view was still that primary cosmic rays were for the most part positive and negative electrons. During 1938-41, Marcel Schein conducted a series of balloon experiments in which he studied the physical properties of cosmic-ray particles in the highest layers of the atmosphere and was able to show that these particles did not behave in at all the way that high-energy electrons were known to behave. He concluded that electrons did not appear in any appreciable amount among primary cosmic rays, and that the incoming radiation consisted most likely of protons ${ }^{1}$.

These experiments remain one of the milestones of cosmic-ray research. However, they were only the beginning of Marcel Schein's work in this field of science. Soon his interest became focused on the most energetic particles present in the primary cosmic radiation and on the remarkable and unbelievably intricate processes that occur when these particles strike atomic nuclei. Marcel Schein was a pioneer in the study of nuclear interactions at energies far exceeding those provided by man-made machines. At the time of his death, he had just returned from an expedition to the Caribbean where, in an effort to extend further and improve the experimental data on high-energy interactions, he had flown the largest stack of nuclear emulsions ever used in any experiment. This stack, which is now being processed, will undoubtedly contain invaluable data the analysis and interpretation of which will keep many physicists busy for a number of years. 
Marcel Schein was keenly interested in international scientific collaboration. He travelled extensively in foreign countries, providing great stimulation through his lectures and his informal contacts with scientific workers. He participated most actively in practically all major international conferences dealing with subjects within his field of interest. His last experiment, which I mentioned before, was a truly international venture, with a large number of laboratories, both in the United States and abroad, participating in the analysis of the experimental results.

Marcel Schein was, in many ways, a remarkable man. For him science was a passionate search for the new and the unknown, involving all his scientific skills, as well as his deepest emotions. His sharp mind, his keen intuition, his irresistible enthusiasm and his intense personality will be long remembered by his many friends, pupils, and professional associates in all parts of the world. Bruno Rossi

${ }^{1}$ Schein, M., Jesse, W. P., and Wollan, E. O., Phys. Rev., 59, 615 (1941).

\section{Prof. G. P. Mazumdar}

Prof. G. P. Mazumdar died suddenly on November 21. He was born on February 18, 1894, at Gopalnagar in the District of Pabna, North Bengal (now in East Pakistan); the third son of Kali Charan Mazumdar, a wealthy landlord and Zeminder of the district. After obtaining his B.Sc. at the University of Calcutta in 1913, he joined the teaching staff of the Botany Department, Presidency College, Caleutta. He later obtained his B.A. (1916) and M.Sc. in botany (1915), standing first in order of merit, and in 1917 the B.L. degree from the same University. He was eventually appointed a professor of botany in the Bengal Educational Service in the Presidency College, Calcutta, and from 1928 became one of the postgraduate lecturers in botany at the University of Calcutta. In 1938 he went on study leave to England to work on plant anatomy in the University of Leeds under the late Prof. J. H. Priestley and obtained the degree of Ph.D. in 1940. He retired from the Government service in 1949 ; but his services were soon requisitioned by the Government of West Bengal for the organization of honours teaching in botany in the Government College, Darjeeling. In December 1951 he was appointed professor of botany and head of the Biology Department, University of Dacca, in East Pakistan, and retired in October 1954. While in Pakistan, he acted as the chairman of the Commission of Courses of the Karachi University and presided over the Section of Biology at the annual session of the Pakistan Association for the Advancement of Science in January 1955. In 1945 he presided over the Section of Botany at the thirty-second Indian Science Congress. He also presided over the Section of Technical Sciences at the All-India Oriental Conference some few years back. He was elected a. Fellow of the Indian Academy of Sciences, Bangalore, and National Institute of Sciences of India (1945). $\mathrm{He}$ was for a long time connected with the Indian Association for the Cultivation of Science, now at Jadavpur, Calcutta, both as a member and a treasurer. He was also member of other Indian learned societies.

Prof. Mazumdar published a large number of scientific papers in numerous journals throughout the world and several scientific Bengali primers, especially in botany. His writings for children on scientific subjects and botany in Bengali have evoked admiration. He also dealt with botany in ancient India in several books and papers. His "Vanaspati" earned for him the Griffith Memorial Prize of the University of Calcutta in 1925. His "Upavana Binoda", (dealing with horticulture in ancient India) was published in 1938. He published other works on the history of botany. The Asiatic Society awarded him the P. Bruhl Memorial Medal in 1955 for his outstanding researches in botany.

R. M. DATTA

\section{NEWS and VIEWS}

Botany at Cambridge : Prof. G. E. Briggs, F.R.S. ON September 30, Prof. G. E. Briggs will retire from the professorship of botany in the University of Cambridge. Since he succeeded Prof. F. T. Brooks in 1948 , he has maintained the notably wide range of teaching and research in the Botany School and has fostered expansion in several branches of the subject. The Department has flourished under his direction, and has benefited greatly from his example of easy friendliness. As a physiologist he has always believed in the value of a quantitative and critical approach both in teaching and research, and his lectures were planned not only to show this but also to indicate the weaknesses of many currently accepted generalizations. $\mathrm{He}_{0}$ is a brilliant teacher, and for those undergraduates and research students who could rise at least part-way towards his high standard, his lectures and supervision provided a never-to-be-forgotten education. His researches on enzyme kinetics, on growth and photosynthesis early brought him a world-wide reputation as a critical and original thinker. More recently he has entered a new field of research, the biophysics of the plant cell, and his success in this work has drawn to him a flourishing group of research students. In 1952 he became president of St. John's College, but he never allowed the duties of this post to curtail the time he gave to the Botany School.

Prof. H. Godwin, F.R.S.

DR. H. GoDwIN, reader in Quaternary research at Cambridge, who has been appointed to succeed Prof. Briggs, is known to a large number of former Cambridge students as an able and enthusiastic teacher of botany at all levels. Outside Cambridge, he may be best known for his large book on the Quaternary history of the British vegetation. His first research was, in fact, in pure plant physiology with Dr. F. F. Blackman, but from early days the inspiration of A. G. Tansley led him to work at Wickon Fen and eventually ecology took up his whole time. Study of fluctuating water-level in the peat and of the effects of this and of cutting reeds on fen vegetation soon directed his attention to the history of this vegetation in the immediate past, and to actual changes in this locality rather than general seral development. Thus he naturally dug in the peat for visible plant remains, and was soon using the methods of pollen 